\title{
Chromogranin A, a Member of Neuroendocrine Secretory Proteins as a Selective Marker for Laboratory Diagnosis of Pheochromocytoma
}

\author{
R. BÍLEK ${ }^{1}$, L. ŠAFǍ̌íK ${ }^{2}$, V. CIPROVÁ ${ }^{3}$, P. VLČEK ${ }^{1}$, L. LISÁ ${ }^{1}$ \\ ${ }^{1}$ Institute of Endocrinology, Prague, ${ }^{2}$ Dept.of Urology, First School of Medicine, Charles \\ University, Prague and ${ }^{3}$ Dept of Pathology, First School of Medicine, Charles University, Prague, \\ Czech Republic
}

Received November 12, 2007

Accepted January 28, 2008

On-line February 13, 2008

\section{Summary}

The function of chromogranin A (CGA) is reviewed, and the radioimmunometric determination of plasma CGA was evaluated as a marker of pheochromocytoma using a comparison of pheochromocytoma patients immediately before surgery (group $P, n=25,635 \pm 451 \mathrm{ng} / \mathrm{ml}$ ) with other groups of patients, i.e. pheochromocytoma patients approximately 1 year after removal of tumor (group PP, $\mathrm{n}=13,69 \pm 33 \mathrm{ng} / \mathrm{ml}$ ), medullary thyroid carcinoma patients (group $M, n=22,106 \pm 59 \mathrm{ng} / \mathrm{ml}$ ), congenital adrenal hyperplasy patients $(n=33,65 \pm 40 \mathrm{ng} / \mathrm{ml})$, and controls $(\mathrm{n}=31,66 \pm 29 \mathrm{ng} / \mathrm{ml})$. A CGA level above cut off value $130 \mathrm{ng} / \mathrm{ml}$ was found in 24 of 25 patients in group $P, 1$ (relapse) of 13 patients in group PP, and 4 of 22 patients in group $M$. In the group $P$ we found a significant association between the size of the tumors removed and plasma CGA concentrations $(p=0.0016)$, and also a significant $(p=0.0016)$ relationship between plasma CGA concentrations and PASS score rating the malignity of pheochromocytoma. We can conclude that plasma CGA concentration as determined by radioimmunometric assay (which is simple without the necessity of special laboratory equipment) is an effective marker of pheochromocytoma with association to malignity and tumor mass.

\section{Key words}

Chromogranin A • Pheochromocytoma - Radioimmunometric assay • Plasma

\section{Corresponding author}

R. Bílek, Institute of Endocrinology, Národní třída 8, 11694 Praha

1, Czech Republic. E-mail: rbilek@endo.cz

\section{Introduction}

Pheochromocytoma, which is a rare catecholamine-producing tumor with preferential localization in the adrenal gland, arises from neuroendocrine chromaffin cells of the adrenal medulla (Guller et al. 2006). It is included in the heterogenous group of neuroendocrine tumors together with carcinoid, gastroenteropancreatic neuroendocrine tumors, pituitary tumors and medullary carcinoma of the thyroid. These tumors originate in neuroendocrine cells characteristic with their production of neurotransmitters, neuromodulators and neuropeptide hormones, with a presence of dense-core secretory granules, and an absence of axons and synapses (Barakat et al. 2004). However, extraadrenal pheochromocytomas have been also described in locations such as the Zuckerkandle organ, bladder, sacrum, testis, rectum, pelvic floor, the upper abdomen in association with celiac, superior mesenteric, and inferior mesenteric ganglia, the thorax, and the neck, most commonly in association with the ninth or tenth cranial nerve ganglion (Frezza et al. 2002). The incidence of pheochromocytoma is similar in both sexes and most frequent between the ages of thirty and fifty. Multiple and bilateral pheochromocytomas constitute 5 to 10 percent of all cases. Pheochromocytoma occurs sporadically or is related to family syndromes such as: syndrome of multiple endocrine neoplasia (MEN), neurofibromatosis, von Hippel-Lindau's disease, Sturge-Weber's syndrome, and tuberous sclerosis. Cases in families with genetic predisposition usually occur at a young age and are 
mostly bilateral and with more aggressive biological behaviour (Tatic et al. 2002).

Chromaffin cells of the adrenal medulla contain chromogranin A (CGA) which is co-stored and coreleased with catecholamines (epinephrine, norepinephrine) from storage granules in the adrenal medulla, plays a catalytic role in granule biogenesis (Mosley et al. 2007). Murray et al. (1987) traced human CGA to chromosome 14 by probing DNA from a hybrid cell panel with specific cDNA. Konecki et al. (1987) isolated a full-length clone encoding human CGA from a lambda-gt10 cDNA library of a human pheochromocytoma. The nucleotide sequence showed that human CGA is a 439 amino acid protein preceded by an 18-residue signal peptide. It was found (Wu et al. 1991) that the CGA gene has 8 exons and 7 introns spanning about $11 \mathrm{~kb}$.

CGA is a member of granins (chromogranins or secretogranins), which are a family of acid proteins present in the secretory granules of a wide variety of endocrine and neuro-endocrine cells with numerous pairs of basic amino acids as potential cleavage sites (Konecki et al. 1987). Granins seem to be the precursors of biologically active peptides, which may act as helper proteins in the packaging of peptide hormones and neuropeptides. Granins exert similar subcellular location. Their structural homology is limited to the short conserved C-terminal region. The granin family of acid secretory proteins consists of the 3 „classic“ granins chromogranin $\mathrm{A}$, which was first isolated from chromaffin cells of the adrenal medulla, chromogranin B (secretogranin I, 657 amino acids long protein) initially characterized in a rat pheochromocytoma cell line, and chromogranin C (617 amino acids) also known as secretogranin II, which was originally described in the anterior pituitary (Taupenot et al. 2003). 4 other acidic secretory proteins considered to be the members of the granin family are secretogranin III (Ottiger et al. 1990), secretogranin IV (Krisch et al. 1986), secretogranin V (Mbikay et al. 2001), and secretogranin VI (Ischia et al. 1997).

Biological function of CGA was investigated using CGA-null mice (Mahapatra et al. 2005). The following were found in these animals: a decrease in chromaffin granule size and number, increase in blood pressure, loss of diurnal blood pressure variation, increase in left ventricular mass and cavity dimensions, decrease in adrenal catecholamine and neuropeptide $\mathrm{Y}$ contents, and an increase in plasma catecholamine and neuropeptide $\mathrm{Y}$ concentrations. The authors concluded that CGA has a definitive role in the autonomic control of circulation. CGA was found to be an "on/off" switch, which is sufficient by itself to drive dense-core secretory granule biogenesis and hormone sequestration in endocrine cells (Kim et al. 2001).

CGA is a precursor of biologically active peptides, which act as autocrine or paracrine negative modulators of the neuroendocrine system. To these peptides belong vasostatin 1 with antiadrenergic effects (Gallo et al. 2007), pancreastatin, which is a strong inhibitor of glucose induced insulin release from the pancreas (Helman et al. 1988), parastatin (parathyroid secretory protein) inhibiting low $\mathrm{Ca}^{2+}$-stimulated parathyroid secretion (Fasciotto et al. 1993), and catestatin, which is a catecholamine release-inhibitory peptide (Rao et al. 2007, Taylor et al. 2000). Knowledge is limited about other peptides derived from CGA such as chromostatin, beta-granin (vasostatin 2), WE-14, GE-25 etc. The proteolysis of CGA is tissue specific, for example pancreastatin was found in alpha cells of pancreas, chromostatin in beta cells of pancreas, but neither pancreastatin nor chromostatin were observed in adrenal chromaffin cells (Cetin et al. 1993).

The primary structure of the CGA molecule prepared by authors according to the ExPASy proteomics server (Gasteiger et al. 2003) of the Swiss Institute of Bioinformatics (access number P10645) is shown in Fig. 1 with mapped CGA-derived peptides and potential glycosylation and phosphorylation sites. 3-Dimensional structural data on CGA is lacking and only catestatin was determined experimentally using nuclear magnetic resonance by Preece et al. (2004). The model of catestatin is also shown in Fig. 1, the 3D-structure of which was constructed by authors using CAChe software (Fujitsu Ltd, Japany) according the XYZ coordinates from Protein Data Bank file (www.rcsb.org/pdb, code 1LV4.pdb).

CGA is secreted by a great variety of peptideproducing endocrine neoplasms such as pheochromocytoma, parathyroid adenoma, medullary thyroid carcinoma, carcinoids, oat-cell lung cancer, pancreatic islet-cell tumors, and aortic-body tumor (O'Connor and Deftos 1986). Nobels et al. (1997) evaluated the clinical usefulness of CGA as a neuroendocrine serum marker. CGA was increased in 50 $\%$ of patients with neuroendocrine tumors $(\mathrm{n}=211)$ and most frequently increased in subjects with gastrinomas (100\%), pheochromocytomas (89\%), carcinoid tumors $(80 \%)$, nonfunctioning tumors of the endocrine pancreas 


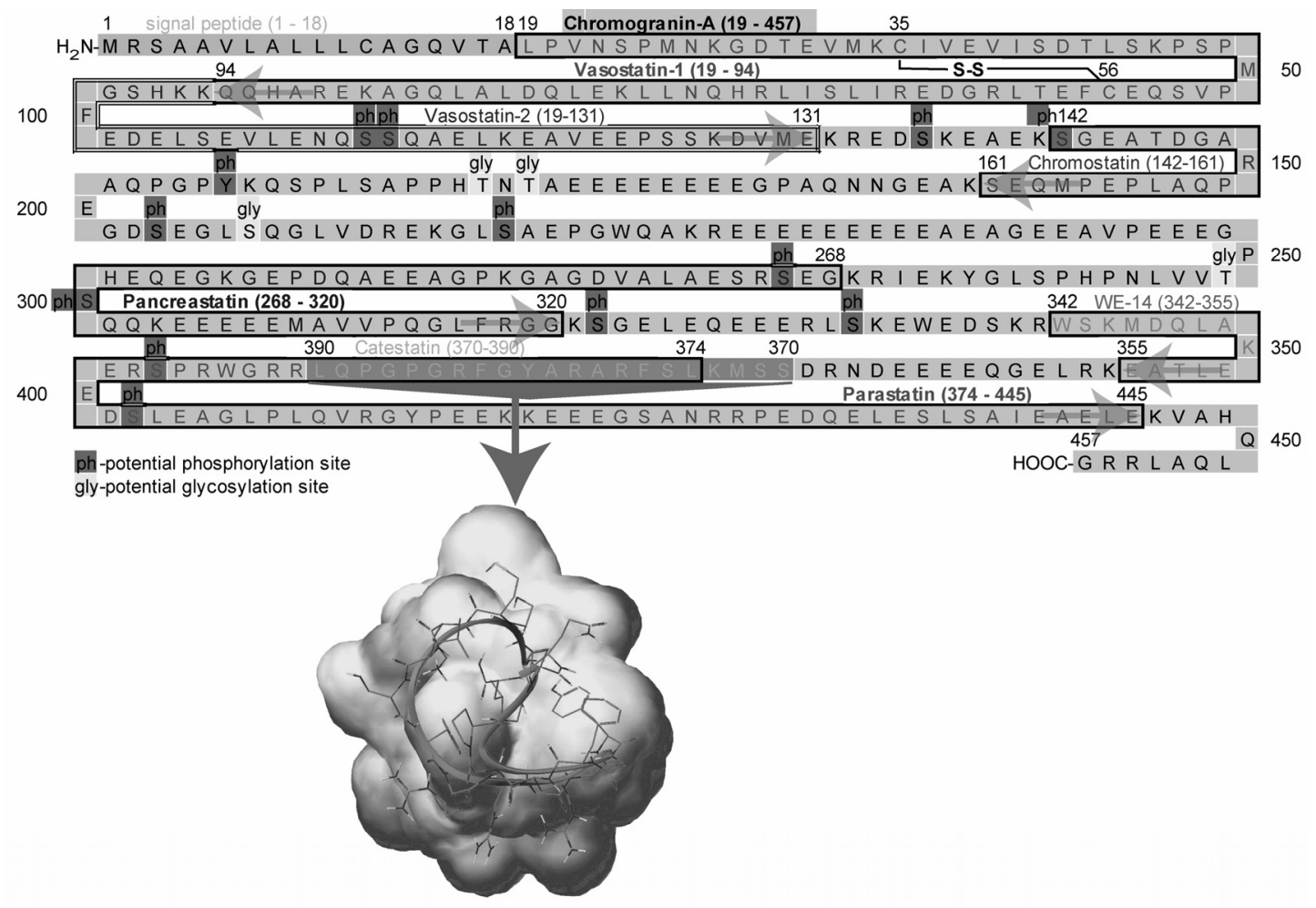

Fig. 1. The primary structure of the chromogranin A (CGA) according the ExPASy proteomics server (Gasteiger et al., 2003) of the Swiss Institute of Bioinformatics (access number P10645) with mapping of biologically active peptides marked as a bold lined arrows. Potential glycosylation sites of CGA are marked gly, potential phosphorylation sites are marked ph. Experimentally determined threedimensional structure of catestatin, part of human CGA (amino acids 370 to 390) using nuclear magnetic resonance (Preece et al. 2004) is shown in the lower part of figure. Model of molecule was constructed using CAChe software (Fujitsu Ltd, Japany) according the XYZ coordinates from the Protein Data Bank file (code 1LV4.pdb).

(69\%), and medullary thyroid carcinomas $(50 \%)$. The highest levels of CGA were observed in subjects with carcinoid tumors. Elevated concentrations of CGA were present in $7 \%$ of control subjects. Nobels et al. (1997) concluded that CGA was the best general neuroendocrine serum marker available at that time. In a group of 63 patients with histologically-proven pheochromocytoma (52 pheochromocytomas and 14 paragangliomas, 14 of the patients had a family history of the disease) a CGA assay was highly efficient in diagnosing pheochromocytomas in the absence of renal insufficiency (d'Herbomez et al. 2007). The evaluation of the CGA immunoradiometric assay (IRMA) in the selection of patients affected by adrenal incidentaloma $(n=144)$ for accurate but high-cost and time-consuming ${ }^{123} \mathrm{I}-$ metaiodobenzyl-guanidine (MIBG) scintigraphy was completed by Giovanella (2005). Circulating CGA concentration was positive in 12 out of 12 patients with pheochromocytoma and negative in 92 out of 92 patients with non-chromaffin adrenal nodules. Feng et al. (2005) described that CGA was detected in all pheochromocytomas $(n=25)$, and exhibited less or no expression in adrenocortical tumors.
A significant positive relationship was demonstrated between tumor mass and serum CGA levels (d'Herbomez et al. 2001, Giovanella et al. 2006, Nobels et al. 1997). An additional important finding is the existence of the statistically significant difference of CGA expression between benign and malignant pheochromocytomas (Feng et al. 2005, Portela-Gomes et al. 2004). Plasma CGA was progressively higher (probability level $\mathrm{p}<0.0001$ ) from control subjects $(48.0 \pm 3.0 \mathrm{ng} / \mathrm{ml})$ to benign pheochromocytoma $(\mathrm{n}=13$, $188 \pm 40.5 \mathrm{ng} / \mathrm{ml}$ ) to malignant pheochromocytoma ( $\mathrm{n}=14$, $2932 \pm 960 \mathrm{ng} / \mathrm{ml}$ ), i.e. markedly elevated chromogranin A may point to malignant pheochromocytoma (Rao et al. 2000).

When comparing CGA with other tests used for laboratory diagnosis of pheochromocytoma (urinary epinephrine, norepinephrine, vanillylmandelic acid and metanephrines determined by high performance liquid chromatography) the immunoradiometric measurement of serum CGA concentrations showed a higher sensitivity, specificity and accuracy, and can be used as a single test for the diagnosis of pheochromocytoma (Giovanella and Ceriani 2002). In pheochromocytoma patients $(n=11)$ 
immunoradiometric assays based on monoclonal antibodies (CgA-RIA CT, CIS bio international) before surgery and again four weeks after tumor removal showed that plasma CGA concentrations determined significantly decreased $(\mathrm{p}<0.001)$ (Cotesta et al. 2005). Measuring plasma CGA is a useful adjunctive test when evaluating patients with adrenal incidentalomas and presumed pheochromocytomas CGA (Giovanella and Ceriani 2002). Patients with adrenocortical tumors usually do not have elevated levels of plasma CGA (Bernini et al. 2004).

In this study we presented our experiences with immunometric determination of plasma CGA in groups of patients who suffered of pheochromocytoma (PHEO), multiple endocrine neoplasia (MEN), medullary thyroid carcinoma (MTC), and congenital adrenal hyperplasia $(\mathrm{CAH})$. Patients with various endocrine disorders other than PHEO, MEN, MTC, and CAH were used as controls.

\section{Methods}

\section{Groups of patients}

Plasma CGA was determined in pheochromocytoma patients aged $47 \pm 14$ (mean \pm standard deviation) years (group $\mathrm{P}, \mathrm{n}=25,13$ males, 12 females) of them were 3 MEN II patients with medullary thyroid carcinoma ( 1 male, 2 females aged $32 \pm 11$ years) immediately before surgery, and approximately 1 year after removal of tumor (group PP, $n=13,7$ males, 6 females). Group M contained MTC (medullary thyroid carcinoma without pheochromocytoma) patients aged $45 \pm 21$ years ( $\mathrm{n}=22$, 9 males, 13 females), group $\mathrm{H}$ were $\mathrm{CAH}$ (congenital adrenal hyperplasy) patients aged $22 \pm 9$ years ( $\mathrm{n}=33,17$ males, 16 females). Controls (group $\mathrm{C}, \mathrm{n}=31,8$ males, 23 females, aged $47 \pm 18$ years) consisted of patients without pheochromocytoma, but who had underwent surgery of adrenal gland because of nonfunctioning adrenal masses $(n=11,3$ males (age $49 \pm 12$ years), 8 females (age $43 \pm 17$ years)). The control group additionally was made up of 7 patients with various adrenal diseases (no pheochromocytoma), 4 hypertensive patients, and 9 patients with thyroid disorder of various etiology (no MTC). Malignity of the surgically removed pheochromocytoma tumors was determined according the PASS score, which has been suggested for biological assessment of pheochromocytomas (Thompson 2002).

\section{Immunoassay of CGA}

A solid-phase two-site immunoradiometric assay was used with primary immobilized monoclonal antibodies

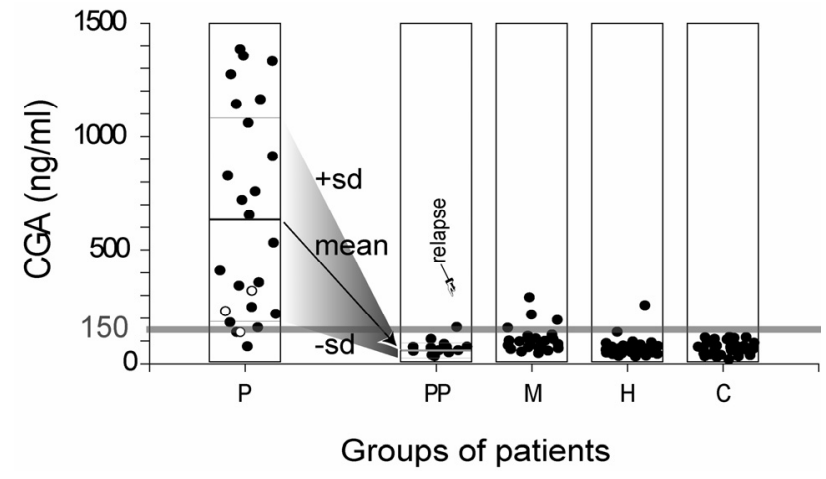

Fig. 2. Plasma chromogranin $A(C G A)$ in various groups of patients: $\mathrm{P}$ - patients with pheochromocytoma immediately before surgery (white points are MEN patients), PP - patients at least 1 year after surgery of pheochromocytoma (relapse of disease in 1 subject), M - medullary thyroid carcinoma patients, $\mathrm{H}$ - patients with congenital adrenal hyperplasy, $\mathrm{C}$ - controls (patients with various endocrine disorders, but no pheochromocytoma or MTC).

and secondary radioiodinated monoclonal antibodies, both directed against the central domain of the molecule (145245), which is less sensitive to proteolysis (manufacturer CIS bio international, France; code CGA-RIACT). CGA was measured in $50 \mu \mathrm{l}$ EDTA - plasma samples. The reference range according to the manufacturer was 20-150 $\mathrm{ng} / \mathrm{ml}$ for plasma EDTA samples, and 19.4 - $98.1 \mathrm{ng} / \mathrm{ml}$ for serum samples. The capacity of the kit is 42 samples in duplicate, analysis takes two days. Characteristics of the immunometric assay are: intraassay precision $3.8 \% \mathrm{CV}$ (coefficient of variation), interassay precision $5.7 \% \mathrm{CV}$, detection limit $1.5 \mathrm{ng} / \mathrm{ml}$. The concentration of CGA can be increased due to renal failure, hypergastrinemia, or steroid treatment (data of CIS bio international).

\section{Results}

Plasma CGA concentrations are shown in Fig. 2 as a black points, the data for MEN patients is highlighted with a white color. The decrease of CGA concentrations (mean \pm standard deviation (SD)) between groups $\mathrm{P}$ (pheochromocytoma) and PP (postpheochromocytoma) is also shown in the Fig. 2. The mean concentrations of plasma CGA \pm SD were $635 \pm 451$ $\mathrm{ng} / \mathrm{ml}$ in group $\mathrm{P}$ (pheochromocytoma), $69 \pm 33 \mathrm{ng} / \mathrm{ml}$ in group PP (post-pheochromocytoma), $106 \pm 59 \mathrm{ng} / \mathrm{ml}$ in group $\mathrm{M}$ (medullary thyroid carcinoma), $65 \pm 40 \mathrm{ng} / \mathrm{ml}$ in group $\mathrm{H}$ (congenital adrenal hyperplasy), and $66 \pm 29$ $\mathrm{ng} / \mathrm{ml}$ in controls (group C). These statistically significant differences between group P (pheochromocytoma) and all other groups $(\mathrm{p}<0.0001)$ were found using the Student T-test. Group M (medullary thyroid carcinoma) also showed statistically significant differences in comparison 


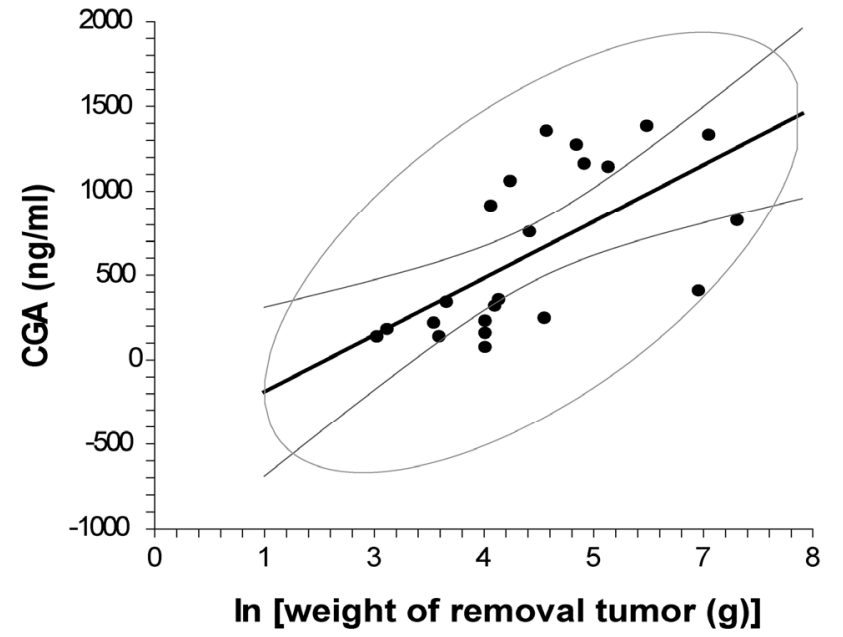

Fig. 3. The association of plasma CGA concentration (group P pheochromocytoma patients) with mass of removal tumour, which is described by the equation: CGA $(\mathrm{ng} / \mathrm{ml})=252 \mathrm{x}$ $\ln [$ weight(g) $]-524$. In the figure are shown confidence limits and probability ellipse.

with all other groups $(\mathrm{p}<0.05)$. Statistically significant differences were not found among groups PP (postpheochromocytoma), group $\mathrm{H}$ (congenital adrenal hyperplasy), and group C (controls). We did not find an association of CGA concentration with age in pheochromocytoma patients or any other group, whether patients or controls. A statistically significant association concerning the size of the removed tumor and CGA concentration was found in group $P$ (pheochromocytoma), where plasma CGA is dependent on the mass of the removed tumor $(\mathrm{p}=0.0016)$ according the equation: CGA $(\mathrm{ng} / \mathrm{ml})=252 \cdot \ln [$ weight $(\mathrm{g})]-524$. Pearson correlation coefficient for this equation has a value of 0.6319 , Spearman correlation coefficient is 0.7942 , and R-squared is 0.3993. The association between CGA and mass of the removed tumor is shown in Fig. 3. We found also an association of CGA concentration with PASS score (malignity), which was statistically significant $(\mathrm{p}=0.0016$ ). The equation of this dependence is: $\operatorname{CGA}(\mathrm{ng} / \mathrm{ml})=126 . \mathrm{PASS}+29$, where the Pearson correlation coefficient is 0.6324 , Spearman correlation coefficient is 0.7158 , and R-squared is 0.4000 . The association between CGA and PASS is shown in Figure 4.

\section{Discussion}

CGA immunoradiometric assay employs a simple and feasible technology. It was found (Giovanella et al. 2006) that this kind of CGA determination in plasma or serum is as sensitive as, and slightly more

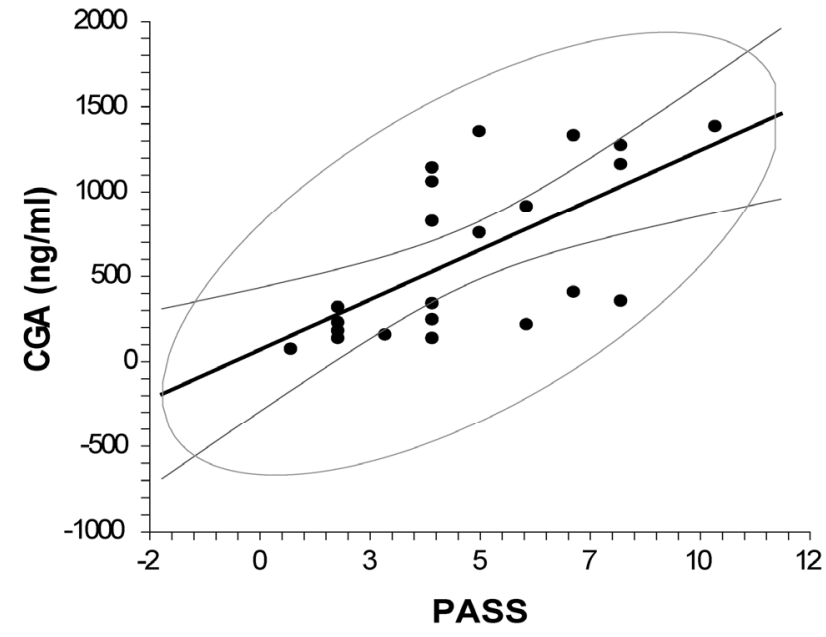

Fig. 4. The association of plasma CGA concentration (group P pheochromocytoma patients) with PASS score, which is described by the equation: CGA $(\mathrm{ng} / \mathrm{ml})=126 \times$ PASS +29 . In the figure are shown confidence limits and probability ellipse.

accurate than HPLC determined plasma metanephrines in chromaffin-tumors detection. Currently, two different methods for assaying CGA, immunoradiometric assay (IRMA) and enzyme-linked immunosorbent assay (ELISA) are widely used in routine practice. When comparing of these assays, the coefficients of variation increased approximately five-fold when shifting from the IRMA to the ELISA method (Verderio et al. 2007). In addition, no antihypertensive drugs interfered with the analysis of CGA levels. However, some false positive results have to be mentioned in the presence of renal impairment, hypergastrinemia, and corticotherapy (Biausque et al. 2003, Hsiao et al. 1991).

Our results concerning the measurement of circulating CGA are in agreement with the fact that plasma CGA is elevated in pheochromocytoma patients. Statistically significant differences in circulating CGA among these patients and other groups in the study uniquely determine the plasma CGA as a suitable marker of pheochromocytoma. Post-operative levels of plasma CGA determined at least one year after tumor removal (group PP) were normal with one exception - a relapse of pheochromocytoma was diagnosed in this one patient. From this point of view, the repeated measurement of circulating CGA over a period of months following removal of a tumor is a good indicator of remise or relapse of the disease.

Elevated plasma CGA concentrations were observed in part of the MTC patients, and group M has also shown statistically significant differences in comparison with all other groups. This is in accordance 
with the fact that the increased concentrations of circulating CGA were found not only in pheochromocytoma but also in other species of neuroendocrine tumors. Medullary thyroid cancer (MTC) shares biochemical features with these tumors but the particular characteristics are largely unexplored. For example serum CGA was increased in 12 of 45 medullary thyroid carcinoma patients with elevated calcitonin levels and in 4 of 16 medullary thyroid carcinoma patients with undetectable calcitonin levels (Guignat et al. 2001). It is important to note the finding (de Groot et al. 2006) that in addition to plasma calcitonin, only carcinoembryonic antigen and CGA could differentiate between stable and progressive MTC, and both are most useful markers in the follow-up of MTC. From our results (Fig. 2) it is evident that increased concentrations of plasma CGA were found in $18 \%$ (4 from 22) of MTC patients. From this point of view CGA is not a suitable marker of MTC, but it is important for detection in MEN patients where MTC is together with pheochromocytoma as part of the syndrome. The increased concentrations of plasma CGA in the rest of patients (groups H, C) were negligible (1 patient in group $\mathrm{H}$ under a corticosteroid treatment).

There are other situations where circulating CGA is increased. The high levels of CGA correspond with serious diseases found in human subjects. Immunoreactive CGA was observed not only in adrenal chromaffin cells but also in alpha cells of the pancreas (Cetin et al. 1993). Positive and negative predictive values of circulating CGA were 84 and $78 \%$ respectively (90\% specificity and $68 \%$ sensitivity) for pancreatic neuroendocrine tumors (Zatelli et al. 2007). Neuroendocrine differentiation in prostate cancer, promoted by neuroendocrine cell secreted products including CGA, appears to be associated with tumor progression, poor prognosis, and hormone-refractory disease (Adolf et al. 2007). Plasma CGA levels in prostate cancer increase with the severity of the disease and were associated with a poor survival prognosis in patients (Hirano et al. 2007). CGA has also been associated with some non-neuroendocrine tumors and it was elevated in 34/72 patients with breast cancer, 11/21 with lung cancer, 10/28 with gastrointestinal cancer, 7/12 with gynaecological cancer, 6/9 with genitourinary cancer, 5/5 with haematological cancer, and 3/4 with head and neck cancer (Tropea et al. 2006). CGA is produced by human myocardium and exerts negative inotropic and lusitropic effects on mammalian heart. Patients with dilated cardiomyopathy or hypertrophic cardiomyopathy showed increased CGA plasma levels, an increase, which was not found in controls (Pieroni et al. 2007).

Increased levels of CGA correlate with pheochromocytoma tumor mass. The correlation is lower in large tumors with mass available over $400 \mathrm{~g}$ (Fig. 3), we therefore used the logaritmic values of mass of the removed tumors. The explanation for this lower correlation may be found in pathology, since extremely large tumors are frequently filled, at least partially, with old blood clots or old posthemorrhagic cysts and the amount of functioning tissue is proportionally smaller. The association of CGA concentration with PASS score (malignity) in pheochromocytoma patients (Fig. 4) is very important, since it supports the predictivity of chromogranin A as a malignant marker.

We can conclude that plasma CGA concentration is an effective marker of pheochromocytoma with association to the malignity and tumor mass. The radioimmunometric determination of CGA is simple without the necessity of special laboratory equipment. Generally, the increased level of circulating CGA can also be an indicator of other serious diseases of the neuroendocrine system, including nonneuroendocrine tumors and cardiomyopathy. We further expect that simultaneously determined plasma CGA and free metanephrines can substantially enrich laboratory diagnosis of pheochromocytoma.

\section{Conflict of Interest}

There is no conflict of interest.

\section{Acknowledgements}

The work was supported by the grant No 8519-3 of the Internal Grant Agency, Ministry of Health, Czech Republic.

\section{References}

ADOLF K, WAGNER L, BERGH A, STATTIN P, OTTOSEN P, BORRE M, BIRKENKAMP-DEMTRODER K, ORNTOFT TF, TORRING N: Secretagogin is a new neuroendocrine marker in the human prostate. Prostate 67: 472-484, 2007.

BARAKAT MT, MEERAN K, BLOOM SR: Neuroendocrine tumours. Endocr Relat Cancer 11: 1-18, 2004. 
BERNINI GP, MORETTI A, BORGIOLI M, BARDINI M, MICCOLI P, BERTI P, BASOLO F, FAVIANA P, BIRINDELLI R, SALVETTI A: Plasma and tissue chromogranin in patients with adrenocortical adenomas. J Endocrinol Invest 27: 821-825, 2004.

BIAUSQUE F, JABOURECK O, DEVOS P, D'HERBOMEZ M, HAINAUT P, CARRE A, MOUNIER-VEHIER C: Clinical significant of serum chromogranin A levels for diagnosing pheochromocytoma in hypertensive patients. Arch Mal Coeur Vaiss 96 780-783, 2003.

CETIN Y, AUNIS D, BADER MF, GALINDO E, JORNS A, BARGSTEN G, GRUBE D: Chromostatin, a chromogranin A-derived bioactive peptide, is present in human pancreatic insulin (beta) cells. Proc Natl Acad Sci USA 90: 2360-2364, 1993.

COTESTA D, CALIUMI C, ALO P, PETRAMALA L, REALE MG, MASCIANGELO R, SIGNORE A, CIANCI R, D'ERASMO E, LETIZIA C: High plasma levels of human chromogranin A and adrenomedullin in patients with pheochromocytoma. Tumori 91: 53-58, 2005.

DE GROOT JW, KEMA IP, BREUKELMAN H, VAN DER VEER E, WIGGERS T, PLUKKER JT, WOLFFENBUTTEL BH, LINKS TP: Biochemical markers in the follow-up of medullary thyroid cancer. Thyroid 16: 1163-1170, 2006.

D'HERBOMEZ M, GOUZE V, HUGLO D, NOCAUDIE M, PATTOU F, PROYE C, WEMEAU JL, MARCHANDISE X: Chromogranin A assay and (131)I-MIBG scintigraphy for diagnosis and follow-up of pheochromocytoma. J Nucl Med 42: 993-997, 2001.

D'HERBOMEZ M, FORZY G, BAUTERS C, TIERNY C, PIGNY P, CARNAILLE B, PATTOU F, WEMEAU JL, ROUAIX N: An analysis of the biochemical diagnosis of 66 pheochromocytomas. Eur J Endocrinol 156: 569575, 2007.

FASCIOTTO BH, TRAUSS CA, GREELEY GH, COHN DV: Parastatin (porcine chromogranin A347-419), a novel chromogranin A-derived peptide, inhibits parathyroid cell secretion. Endocrinology 133: 461-466, 1993.

FENG C, LI HZ, YAN WG, LUO YF, CAO JL: The expression and significance of chromogranin A and synaptophysin in adrenal gland tumors. Zhonghua Zhong Liu Za Zhi 27: 486-488, 2005.

FREZZA EE, IKRAMUDDIN S, GOURASH W, SCHAUER P: Laparoscopic resection of a large periadrenal nonmalignant pheochromocytoma. Surg Endosc 16: 362-363, 2002.

GALLO MP, LEVI R, RAMELLA R, BRERO A, BOERO O, TOTA B, ALLOATTI G: Endothelium-derived nitric oxide mediates the antiadrenergic effect of human vasostatin-1 in rat ventricular myocardium. Am J Physiol 292: H2906-H2912, 2007.

GASTEIGER E, GATTIKER A, HOOGLAND C, IVANYI I, APPEL RD, BAIROCH A: ExPASy: The proteomics server for in-depth protein knowledge and analysis. Nucleic Acids Res 31: 3784-3788, 2003.

GIOVANELLA L: Serum chromogranin-A assay in differential diagnosis of incidentally discovered adrenal masses. Anticancer Res 25: 1547-1550, 2005.

GIOVANELLA L, CERIANI L: Serum chromogranin-alpha immunoradiometric assay in the diagnosis of pheochromocytoma. Int J Biol Markers 17: 130-134, 2002.

GIOVANELLA L, SQUIN N, GHELFO A, CERIANI L: Chromogranin A immunoradiometric assay in diagnosis of pheochromocytoma: comparison with plasma metanephrines and 123I-MIBG scan. Q J Nucl Med Mol Imaging 50: 344-347, 2006.

GUIGNAT L, BIDART JM, NOCERA M, COMOY E, SCHLUMBERGER M, BAUDIN E: Chromogranin A and the alpha-subunit of glycoprotein hormones in medullary thyroid carcinoma and phaeochromocytoma. Br J Cancer 84: 808-812, 2001.

GULLER U, TUREK J, EUBANKS S, DELONG ER, OERTLI D, FELDMAN JM: Detecting pheochromocytoma: defining the most sensitive test. Ann Surg 243: 102-107, 2006.

HELMAN LJ, AHN TG, LEVINE MA, ALLISON A, COHEN PS, COOPER MJ, COHN DV, ISRAEL MA: Molecular cloning and primary structure of human chromogranin A (secretory protein I) cDNA. $J$ Biol Chem 263: 11559-11563, 1988. 
HIRANO D, MINEI S, SUGIMOTO S, YAMAGUCHI K, YOSHIKAWA T, HACHIYA T, KAWATA N, YOSHIDA T, TAKAHASHI S: Implications of circulating chromogranin A in prostate cancer. Scand J Urol Nephrol 41: 297-301, 2007.

HSIAO RJ, PARMER RJ, TAKIYYUDDIN MA, O'CONNOR DT: Chromogranin A storage and secretion: sensitivity and specificity for the diagnosis of pheochromocytoma. Medicine (Baltimore) 70: 33-45, 1991.

ISCHIA R, LOVISETTI-SCAMIHORN P, HOGUE-ANGELETTI R, WOLKERSDORFER M, WINKLER H, FISCHER-COLBRIE R: Molecular cloning and characterization of NESP55, a novel chromogranin-like precursor of a peptide with 5- $\mathrm{HT}_{1 \mathrm{~B}}$ receptor antagonist activity. J Biol Chem 272: 11657-11662, 1997.

KIM T, TAO-CHENG JH, EIDEN LE, LOH YP: Chromogranin A, an "on/off" switch controlling dense-core secretory granule biogenesis. Cell 106: 499-509, 2001.

KONECKI DS, BENEDUM UM, GERDES HH, HUTTNER WB: The primary structure of human chromogranin A and pancreastatin. J Biol Chem 262: 17026-17030, 1987.

KRISCH K, BUXBAUM P, HORVAT G, KRISCH I, NEUHOLD N, ULRICH W, SRIKANTA S: Monoclonal antibody HISL-19 as an immunocytochemical probe for neuroendocrine differentiation: its application in diagnostic pathology. Am J Pathol 123: 100-108, 1986.

MAHAPATRA NR, O'CONNOR DT, VAINGANKAR SM, SINHA HIKIM AP, MAHATA M, RAY S, STAITE E, WU H, GU Y, DALTON N, KENNEDY BP, ZEIGLER MG, ROSS J Jr, MAHATA SK: Hypertension from targeted ablation of chromogranin A can be rescued by the human ortholog. J Clin Invest 115: 1942-1952, 2005.

MBIKAY M, SEIDAH NG, CHRETIEN M: Neuroendocrine secretory protein 7B2: structure, expression and functions. Biochem J 357: 329-342, 2001.

MOSLEY CA, TAUPENOT L, BISWAS N, TAULANE JP, OLSON NH, VAINGANKAR SM, WEN G, SCHORK NJ, ZIEGLER MG, MAHATA SK, O'CONNOR DT: Biogenesis of the secretory granule: chromogranin a coiled-coil structure results in unusual physical properties and suggests a mechanism for granule core condensation. Biochemistry 46: 10999-11012, 2007.

MURRAY SS, DEAVEN LL, BURTON DW, O'CONNOR DT, MELLON PL, DEFTOS LJ: The gene for human chromogranin A (CgA) is located on chromosome 14. Biochem Biophys Res Commun 142: 141-146, 1987.

NOBELS FRE, KWEKKEBOOM DJ, COOPMANS W, SCHOENMAKERS CHH, LINDEMANS J, DE HERDER WW, KRENNING EP, BOUILLON R, LAMBERTS SWJ: Chromogranin A as serum marker for neuroendocrine neoplasia: comparison with neuron-specific enolase and the alpha-subunit of glycoprotein hormones. J Clin Endocr Metab 82: 2622-2628, 1997.

O'CONNOR DT, DEFTOS LJ: Secretion of chromogranin A by peptide-producing endocrine neoplasms. New Eng $J$ Med 314: 1145-1151, 1986.

OTTIGER HP, BATTENBERG EF, TSOU AP, BLOOM FE, SUTCLIFFE JG: 1B1075: a brain- and pituitary-specific mRNA that encodes a novel chromogranin/secretogranin-like component of intracellular vesicles. $J$ Neurosci 10: 3135-3147, 1990.

PIERONI M, CORTI A, TOTA B, CURNIS F, ANGELONE T, COLOMBO B, CERRA MC, BELLOCCI F, CREA F, MASERI A: Myocardial production of chromogranin A in human heart: a new regulatory peptide of cardiac function. Eur Heart $J$ 28: 1117-27, 2007.

PORTELA-GOMES GM, STRIDSBERG M, GRIMELIUS L, FALKMER UG, FALKMER S: Expression of chromogranins $\mathrm{A}, \mathrm{B}$, and $\mathrm{C}$ (secretogranin II) in human adrenal medulla and in benign and malignant pheochromocytomas. An immunohistochemical study with region-specific antibodies. APMIS 112: 663-673, 2004.

PREECE NE, NGUYEN M, MAHATA M, MAHATA SK, MAHAPATRA NR, TSIGELNY I, O'CONNOR DT: Conformational preferences and activities of peptides from the catecholamine release-inhibitory (catestatin) region of chromogranin A. Regul Pept 118: 75-87, 2004.

RAO F, KEISER HR, O'CONNOR DT: Malignant pheochromocytoma. Chromaffin granule transmitters and response to treatment. Hypertension 36: 1045-1052, 2000. 
RAO F, WEN G, GAYEN JR, DAS M, VAINGANKAR SM, RANA BK, MAHATA M, KENNEDY BP, SALEM RM, STRIDSBERG M, ABEL K, SMITH DW, ESKIN E, SCHORK NJ, HAMILTON BA, ZIEGLER MG, MAHATA SK, O'CONNOR DT: Catecholamine release-inhibitory peptide catestatin (chromogranin A(352372)): naturally occurring amino acid variant Gly364Ser causes profound changes in human autonomic activity and alters risk for hypertension. Circulation 115: 2271-2281, 2007.

TATIC S, HAVELKA M, PAUNOVIC I, BOZIC V, DIKLIC A, BRASANAC D, JANKOVIC R, JANCICZGURICAS M: Pheochromocytoma-pathohistologic and immunohistochemical aspects. Srp Arh Celok Lek 130: 7-13, 2002.

TAUPENOT L, HARPER KL, O'CONNOR DT: The chromogranin-secretogranin family. New Engl J Med 348: $1134-$ $1139,2003$.

TAYLOR CV, TAUPENOT L, MAHATA SK, MAHATA M, WU H, YASOTHORNSRIKUL S, TONEFF T, CAPORALE C, JIANG Q, PARMER RJ, HOOK VY, O'CONNOR DT: Formation of the catecholamine release-inhibitory peptide catestatin from chromogranin A. Determination of proteolytic cleavage sites in hormone storage granules. J Biol Chem 275: 22905-22915, 2000.

THOMPSON LD: Pheochromocytoma of Adrenal gland Scaled Score (PASS) to separate benign from malignant neoplasms: a clinicopathologic and immunophenotypic study of 100 cases. Am J Surg Pathol 26: 551-566, 2002.

TROPEA F, BALDARI S, RESTIFO G, FIORILLO MT, SURACE P, HERBERG A: Evaluation of chromogranin A expression in patients with non-neuroendocrine tumours. Clin Drug Investig 26: 715-722, 2006.

VERDERIO P, DITTADI R, MARUBINI E, PIZZAMIGLIO S, GION M, DE APOLLONIA L, PARADISO A, INQAT GROUP: An Italian program of External Quality Control for chromogranin A (CgA) assay: performance evaluation of CgA determination. Clin Chem Lab Med 45: 1244-1250, 2007.

WU HJ, ROZANSKY DJ, PARMER RJ, GILL BM, O'CONNOR DT: Structure and function of the chromogranin A gene: clues to evolution and tissue-specific expression. J Biol Chem 266: 13130-13134, 1991.

ZATELLI MC, TORTA M, LEON A, AMBROSIO MR, GION M, TOMASSETTI P, DE BRAUD F, DELLE FAVE G, DOGLIOTTI L, DEGLI UBERTI EC, ITALIAN CROMANET WORKING GROUP: Chromogranin A as a marker of neuroendocrine neoplasia: an Italian Multicenter Study. Endocr Relat Cancer 14: 473-482, 2007. 